\title{
Levofloxacin が奏効した腸チフスの一症例
}

\author{
国立呉病院内科 ${ }^{1)}$, 国立呉病院臨床検査科細菌室 ${ }^{21}$ \\ 栗村 \\ 統 ${ }^{1)}$ 大石あを(1) 田村 律 ${ }^{1)}$ 土井 秀之 ${ }^{2)}$
}

(平成 4 年 2 月 18 日受付)

(平成 4 年 4 月 14 日受理)

Key words: Levofloxacin, Typhoid fever

我々は1981年来成人の腸チフス患者, 保菌者に norfloxacin ${ }^{1)}$, ofloxacin(OFLX $)^{23)}$ を投与し，そ の成績について報告を行ってきた。今回新たに開 発された OFLXの活性体とされる1体のみから 構成される levofloxacin(LVFX)を使用する機会 を得，腸チフスの一症例に投与した。

症例：65歳, 女性.

主訴：発熱, 下痢, 血尿。

既往歷: 甲状腺腫手術 29歳, HBV carrier.

家族歴：特記すべき事項なし。

現病歴：1990年 6 月中旬に感冒様の症状があっ たが，家庭薬の服用により一時軽快した。 6 月下 旬に下利がみられたが，これも軽快した。7 7 日より午後から夜間にかけて $38^{\circ} \mathrm{C}$ 前後の発熱をみ るようになった。近医を受診, 血尿を指摘され腎 孟腎炎と診断されたが，症状が好転しないため 7 月10日同院に入院した. 同日血液培養が施行され, cefixime が投与されたが，解熱しないため 7 月 13 日に国立吳病院に転院となった。

入院時現症: 身長 $149 \mathrm{~cm}$, 体重 $51.0 \mathrm{~kg}$, 体温 $38.7^{\circ} \mathrm{C}$, 意識明瞭, 脈拍 $120 /$ 分, 不整なし, 血圧 $138 / 88 \mathrm{mmHg}$, 前胸部から腹部にかけて数個のバ ラ疹があり, 右季肋部に軽度の圧痛がある以外特 に異常を認めない。

入院時検查成績: 末梢血中白血球数 $6,000 /$ $\mathrm{mm}$, 肝腎機能正常, CRP 值 $17.9 \mathrm{mg} / \mathrm{dl}$, 赤沈值 64 $\mathrm{mm} /$ 時, Widal 反応はチフス菌に対し $\times 80$, 血液

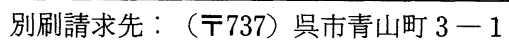
国立只病院内科 栗村 統
培養 5 回, 尿, 粪便培養それぞれ 1 回施行したが, いずれの検体からもチフス菌は検出されなかっ た。しかし入院 3 日前に近医で施行された血液培 養よりチフス菌が検出された。第 2 病院日より LVFX $600 \mathrm{mg} /$ 日 (毎食後, 1 日 3 回分服)の投与 を開始した。体温は翌日より $37^{\circ} \mathrm{C}$ 台となり，6日 目より全く平熱となった。入院時に見られた下㢉， 血尿も軽快した。10日目には CRP 值も正常化し た。投与中に軽度の上昇をみた GOT, GPT 值は 本剂投与中に正常化した. LVFX の投与は14日間 で終了した。翼便からの排菌のないことを確認し たのち，第33病院日に退院した。 6 カ月後まで再 排菌，再発は見られない. LVFX 投与によると思 われる重大な副作用, 検査値異常は認められな かった。

\section{考 察}

OFLX が腸チフスに有効であることはすでに われわれも報告した。従って本剂が腸チフスに効 果を示すことは，投与前から充分に想像された。 LVFX は理論的には OFLX の $1 / 2$ 量で OFLX と 同程度の効果が期待出来るものと考光, OFLX $1,200 \mathrm{mg} /$ 日に相当する LVFX $600 \mathrm{mg}$ /日を投与 した.さらに血清中の OFLX 活性を確認するため 投与後第 7 および第14日に早朝より就寝前まで, 血清中の抗菌活性をdisc 法により OFLXを標準 として測定し，すでに報告した OFLX 投与例と比 較した。本例の血清中 OFLX 活性の推移には両測 定日に差がなく，それぞれ 6 時には $3.25 \mu \mathrm{g} / \mathrm{ml}$, $2.97 \mu \mathrm{g} / \mathrm{ml}, 21$ 時には $7.21 \mu \mathrm{g} / \mathrm{ml}, 8.1 \mu \mathrm{g} / \mathrm{ml}$ で, 
日中は $5.6 \mu \mathrm{g} / \mathrm{ml}$ から $8.1 \mu \mathrm{g} / \mathrm{ml}$ の濃度が保持さ れた。既に報告した OFLX $1,200 \mathrm{mg} /$ 日投与例よ りやや低く，900mg/日投与例より高く, ほぼ期待 通りの血中抗菌活性が得られたものと考兄られ る. 同容量の LVFX とOFLX の副作用発現率が 同等とすると, OFLX 量に換算して倍量の投与が 可能であり, 腸チフスに限らず OFLX 投与の対象 でなかったより重篤な疾患も投与対象となろら。

\section{文献}

1）栗村 統, 他：腸チフス及びチフス菌保菌者に対 するAM-715の効果一続報一. Chemotherapy, $30: 1286-1296,1982$.

2）栗村 統，他：Ofloxacinが奏効した腸チフスの 1 症例. 感染症誌, $58: 932-935,1984$.

3）栗村 統, 他：腸チフス患者ならびに保菌者に対 する Ofloxacin の臨床的細菌学的効果に関する検 討. 感染症誌, $63: 623-632,1989$.

Efficacy of Levofloxacin on Typhoid Fever

Osamu KURIMURA, Aoi OOISHI \& Ritsu TAMURA

Department of Internal Medicine, Kure National Hospital

Hideyuki DOI

Department of Clinical Laboratory, Kure National Hospital 